since direct pathways to the adrenal cortex are lacking ${ }^{22}$. In conclusion, it should be emphasized that this article deals only with a summary of the group $A$ findings. These significant findings with group $A$ make it apparent that large-scale experimental laboratory investigations on the effects of various specific environmental stressors on biological adaptation to repeated stress, rato of ageing and differential mortality have become feasible. When the complete experimental findings of groups $B, C, D$ and $E$ covering the entire life-span are completed and analysed, it will be possible to make a direct multi-variate statistical assessment of the relative contributions of specific environmental stressors on decreasing capacity to respond to repeated deviations from environmental steady-state conditions with increasing age, as well as establish a possible acceleration or even inhibition of the ageing process from an evaluation of specific and controlled environmental effects on differential mortality.

This work was supported by a research grant from the U.S. National Institutes of Health.

${ }^{\prime}$ Shock, N. W., Aging ... Some Social and Biological Aspects, Pub. No. 65 (Amer. Assoc. Adv. Sci., Wash., D.C., 1960).

${ }^{2}$ Shock, N. W., Biological Aspects of Aging (Columbia Univ. Press, New York, 1962)
${ }^{3}$ Bourne, G. H., Structural Aspects of Aging (Hafner Publ. Co., Inc., New York, 1981).

${ }^{4}$ Strehler, B. L., Time, Cells and Aging (Academic Press, Inc., New York, 1962)

${ }^{6}$ Curtis, H. J., Science, 141, 686 (1983).

- Korenchevsky, V., Physiological and Pathological Ageing (Hafner Publ. Co., Inc., New York, 1961).

'Verzar, F., J. Gerontol., 13, 6 (1958).

${ }^{8}$ Bourliere, F., J. (Yerontol., 13, 16 (1958).

${ }^{\circ}$ Kibler, H. H., Silsby, H, D., and Jolnnson, H. D., J. Gerontol., 18, 235 (1963).

ro Meier, G. W., Foshee, D. P., Mathenr, jum., A. I'., and Carr, F., Rad. Res. 16, $130(1962)$

${ }^{11}$ Strehler, B. L., The Biology of Aging (Amer. Inst. Biol. Sci., Wash., D.C., $1960)$.

12 Trujillo, T. T., Spalding, J. F., and Langham, W. H., Rad. Res., 16, 144 (1962).

${ }^{13}$ Samorajski, 'T, Rolsten, C., and Collins, R. L., Anat. Rec.,148, 330 (1964).

I4 Samorajski, T., Keefe, J. R., and Ordy, J. M., J. Gerontol., 19, 262 (1964).

${ }^{15}$ Samorajski, T., Rolsten, C., and Ordy, J. Y., Amer. J. Clin. Pathol., 38, 645 (1962).

16 Werboff, J., and Havlena, J., Psych. Rep., 10, 395 (1962).

it Iuucan, I. W., J. Biol. Chem, 229, 563 (1957).

18 Sinex, F. M., Seience, 134, 1402 (1963).

19 Javne, F. P., J. Gerontol, 12, 227 (1963).

${ }^{20}$ Ohno. T., Tohoku J. Exp. Med., 77, 195 (1962)

21 Thiessen, D. D., and Nealey, Y. G., Endocrinol., 71, 267 (1962).

22 Vogt, M., Qutit. J. Exp. Physiol, 39, 245 (1954).

\title{
OBITUARY
}

\section{Prof. E. F. Freundlich}

THE death at Wiesbaden of Prof. E. F. Freundlich on July 25 at the age of seventy-nine has deprived the astronomical world of an impressive personality, and one of the few remaining links with our science in bygone days before the First World War.

Erwin Finlay Freundlich was born at WiesbadenBiebrich on May 29, 1885, of mixed German-Scottish parentage, and of a large family in which scientific bent was not unknown; the renowned physical chemist, Herbert Freundlich, being one of his older brothers. His university studies in Göttingen led him first to a doctorate in mathematics as a student of Felix Klein; but it was Klein who deflected his career to astronomy by recommending his young scholar in 1910 to an assistantship at the Royal Observatory at Berlin.

The time when Freundlich joined the ranks of astronomers was a pregnant period in the outgrowth of our science, with the relativity theory approaching the prime of its life; and Freundlich with his mathematical background was particularly well prepared to follow its implications. Somewhat to the consternation of his more conservative contemporaries (including his director, Herrmann Struve), Freundlich joined with enthusiasm the early protagonists of relativity and eventually wrote one of the best expository text-books on it at that time (Einstein's Relativitäts-Theorie, Berlin, 1917), an achieve. ment which earned him a lifelong friendship with Sir Arthur Eddington.

Not only did Freundlich set out to defend relativity on theoretical grounds, but he was also one of the first to undertake its experimental verification. To this end, with the support of the Prussian Academy of Sciences, he embarked (with Zurhellen) on the first solar eclipse expedition to measure the light deflexion in the gravitational field of the Sun in Russia, in August 1914. This effort unfortunately came to naught, for the outbreak of the First World War a few weeks before the date of the eclipse caused all equipment to be impounded and the astronomers interned. It was many months before the luckless travellers were eventually repatriated; and the actual detection of the relativistic light deflexion had to await the outcome of the Greenwich expeditions in 1919 .
The first decade which followed the First World War marked the high noon in Freundlich's life. It brought him in close touch with Einstein, then himself at the peak of his powers (the large amount of unpublished Einsteiniana in Freundlich's possession should constitute invaluable material for future historians of science); and it was largely his efforts and close contacts with German industrial circles which led in 1921 to the foundation, in Potsdam, of the Einstein Institute with its solar tower (later renamed the Institute for Solar Rosoarch and amalgamated with the observatory), of which Freundlich became the first director. The work of the distinguished group of investigators (including von den Pahlen, von Klüber, Grotrian, Wurm and others) which Freundlich gathered around him is too well known to need elaboration here. In a study of the $K$-effect, von den Pahlen and Freundlich came (by their detection of the double-wave of the $K$-term in longitude) within an ace of the discovery of galactic rotation. The eclipse expedition to Sumatra of 1929 made up for the abortive one of 1914, and, as a result, Freundlich, von Klüber and von Brunn established the light deflexion at the limb of the Sun to be $2 \cdot 2^{\prime \prime} \pm 0 \cdot 1^{\prime \prime}$ - somewhat more than the thooretical prediction of $1.75^{\prime \prime}$. Subsequent work has, on the whole, tended to cluster around the larger value; and this discrepancy (if finally established) may possibly play a similar part in the fate of the relativity theory in years to come as did the secular advance of Mercury's perihelion in Newtonian mechanies.

The advent of the Nazi Government to power in Germany in 1933 interrupted Freundlich's work; and because of his partly Jewish origin he left Potsdam to accept the professorship of astronomy in the University of Istanbul. He remained there for three years (the present Istanbul University Observatory was erected under his direction), and left in 1936 for a similar post in the German University of Prague. The Munich agreement and its aftermath uprooted Freundlich once again after little more than two years of residence in a congonial city and State. This time (declining an invitation to America), at Eddington's initiative he resorted to his Scottish motherland and the University of St. Andrews, where he spent the rest of his active life.

Shortly before that time, the University received a bequest from the late Prof. Gordon Lang for the estab- 
lishment of a new university observatory; and Freundlich was entrusted with its erection as the observatory's first director. The outbreak of the Second World War interrupted this work almost immediately; and in the grim years that followed it took all of Freundlich's energy and determination to carry out his mission in the face of protracted material and man-power shortages-not to speak of perennial financial problems caused by the post. war inflation spiral. As the principal instruments for the new observatory - in keeping with St. Andrews's Gregory tradition-Freundlich wished to erect reflectors of the most modern type-the flat-field Schmidts. In collaboration with Linfoot and Waland, he succeeded in commissioning the 19-in. pilot model in regular service in 1949; but it was one of the disappointments of his life that he was unable to render the full-scale 39 -in. flat-field Schmidt (the largest telescope of this type in the world) fully operational before his retirement.

On reaching the age of seventy in 1955, Freundlich retired from the Napier chair of astronomy at St. Andrews, but retained directorship of the observatory until 1959 , when he finally left Scotland for his native Wiesbaden to spend his years in 'retirement'. If his middle age was often stormy, the evening of his life was calm. In a sense, however, Freundlich never really retired; for until he died he held an honorary professorship in the University of Mainz and his mind continued to remain active. His last book on Celestial Mechanics appeared in 1958. In the last decade of his life, Freundlich was much preoceupied with astronomical red shifts and, in particular, with the fate of the photons which may travel from distant galaxies for hundreds of millions of years through empty space to reach us. Do they retain their original energy unimpaired ? His last paper on this subject appeared in the Zeitschrift für Astrophysik in February of this year.

Death came gently on July 25 to claim the life of a veteran of almost four score years; and his passing is mourned not only by his family but by two generations of grateful students to whom Freundlich gave generous help in various stages of their careers in Germany, Turkey. Czechoslovakia or Britain, and many of whom are scattered all over the world. They will indeed remember him long as a man of forthright character and wide culture (he was an accomplished musician), whose tall stature, unbent by age, and leonine head towered in any gathering over most of his contemporaries. He was always forthright in expressing his views-there was nothing of a politician in him-a true liberal of old vintage and of the type who instinctively evoked also strong feelings in others; very few people who ever met him at a close range remained indifferent to his personality. What greater tribute can a man be paid ?

$\mathrm{He}$ is survived by his wife, Mrs. K. Freundlich, who shared with her husband more than half a century of common life through troubled times; and by his two children and many grandchildren who have made their home in Britain.
ZDENEKK KOPAL

\section{NEWS and VIEWS}

\section{The Royal Society of London: Medal Awards}

THe following awards of medals have been made by the President and the Council of the Royal Society: The Copley Medal, to Prof. S. Chapman, advisory scientific director of the Geophysical Institute, University of Alaska, for his theoretical contributions to terrestrial and interplanetary magnetism, the ionosphere and the aurora borealis; The Rumford Medal, to Prof. H. C. van du Hulst, professor of astronomy in the University of Leiden, for his distinguished work on the scattering processes in the interplanetary medium and his prediction of the $21-\mathrm{cm}$ spectral line from interstellar neutral hydrogen; The Davy Medal, to Prof. M. Calvin, professor of chemistry in the University of California and director of the bioorganic chemistry group in the radiation laboratory, for his pioneering work in chemistry and biology, particularly his elucidation of the photosynthetic pathway for the incorporation of carbon dioxide by plants; The Darwin Medal, to Prof. K. Mather, professor of genetics in the University of Birmingham and Vice-Chancellor elect of the University of Southampton, for his distinguished contributions to knowledge of cytology and genetics; The Sylvester Medal, to Dr. Mary L. Cartwright, Mistress of Girton College and Univorsity reader in the theory of functions in the University of Cambridge, for her distinguished contributions to analysis and the theory of functions of a real and complex variable; The Hughes Medal, to Prof. A. Salam, professor of theoretical physics at the Imperial College of Science and Technology in the University of London, for his distinguished contributions to quantum mechanics and the theory of fundamental particles.

Director of G.P.O. Research:

Mr. R. J. Halsey, C.M.G.

Mr. R. J. Halsey, who retires from the post of director of research at the General Post Office on December 31, was born at Portsmouth in 1902, and was educated at the City and Guilds College on a Royal Scholarship. He took first-class honours degree and diplomas of both the City and Guilds and Imperial College of Science and Technology, He entered the Post Office Engineering Department in 1927, and, until his appointment as assistant engineer-in-chief in 1953, worked at the Post Office Research Station on line transmission. He was in charge of the work that led to the laying of the first-ever repeatered submarine cable, between Anglesey and the Isle of Man, in 1943. As assistant engineer-in-chief he led the Post Office project team on the first Transatlantic telephone cable. He became director of research in 1958 . and in 1959 also a director of Cable and Wireless, Ltd. In 1957 he was made a Companion of the Order of St. Michael and St. George.

\section{Dr. G. H. Metson}

DR. G. H. Metson, who has been appointed to sueceed Mr. Halsey, was born in London in 1907 and joined the Post Office in 1925 as a youth-in-training. His early years with the Post Office were spent in the physics laboratory working on spectrography. Later he transferred to Northern Ireland, where he carried out research on magnetron oscillations and earned his M.Se. and Ph.D. at Queen's University, Belfast. During the War he served with the Royal Corps of Signals, and won the M.C. for gallantry. In 1946 he was back at Dollis Hill as a principal scientific officer in charge of the Thermionies Group set up to study the causes of valve failure. Later his Division started to design and manufacture very-long-life valves. He was awarded a D.Sc. in 1958, and in 1962 received the Institution Premium, the highest award made by the Institution of Flectrical Engineers, for a paper on an electrical engineering subject. He was appointed deputy director of research in 1962 . 